ROCZNIKI TEOLOGICZNE

Tom LXVIII, zeszyt 7 - 2021

DOI: https://doi.org/10.18290/rt21687-8

\title{
PRAWOSŁAWNE DUSZPASTERSTWO WOJSKOWE W OKRESIE MIĘDZYWOJENNYM I W TRAKCIE II WOJNY ŚWIATOWEJ
}

\author{
THE ORTHODOX MILITARY CHAPLAINCY \\ IN THE INTERWAR PERIOD AND DURING WORLD WAR II
}

\begin{abstract}
A b s t r a c t. This article above is to outline the difficult period Orthodoxy development in the Second Polish Republic, i.e. the years 1918-1945. Problems with shaping an unambiguous state thought, establishing a confessional profile, or finally the World War II tragedy augmented already existing problems or evoked new ones. The natural inclination to cultivate the tradition of Western Christianity in Poland had to give way to the post-war conditions of the atheistic program, when the army had to uphold its fidelity to the provisions of the treaties and guard freedom in its new semantic restrictions.
\end{abstract}

Keywords: history; military; war; theology; Orthodox pastoral care.

\section{OKRES MIĘDZYWOJENNY}

Odrodzona w okresie międzywojennym II Rzeczypospolita była państwem wielonarodowościowym i wielowyznaniowym. Znajdowało to swoje odzwierciedlenie w siłach zbrojnych, gdzie duży odsetek stanowili żołnierze wyznania niekatolickiego i narodowości niepolskiej ${ }^{1}$. Podobnie jak miało to miejsce w okresie I Rzeczypospolitej, również i wtedy żołnierze wyznania prawosławnego stanowili w wojsku drugą pod względem liczebności grupę, za katolikami ${ }^{2}$. Fakt ten

Ks. mgr JERZY MoKRAUZ, pułkownik; adres do korespondencji: ul. 3 Maja 58, 37-700 Przemyśl; e-mail: jerzymokrauz@poczta.onet.pl

${ }^{1}$ Jerzy Grzybowski, $W$ stużbie Rzeczypospolitej, Duszpasterstwo wojskowe wyznania prawostawnego w Wojsku Polskim w latach 1919-1949 (Warszawa, 2016), 49.

2 Janusz Odziemkowski, Bolesław Spychała, Duszpasterstwo wojskowe w Drugiej Rzeczypospolitej (Warszawa, 1987), 192. 
stał się przyczyną rozpoczęcia działań związanych z organizacją duszpasterstwa wojskowego w międzywojennej Polsce.

Powstanie prawosławnego duszpasterstwa wojskowego w II Rzeczypospolitej wiąże się z powołaniem w czerwcu 1919 r. Sekcji Religijno-Wyznaniowej, działającej w ramach Departamentu I Mobilizacyjno-Organizacyjnego Ministerstwa Spraw Wojskowych. W skład tej Sekcji wszedł Referat Wyznania Prawosławnego. 1 marca 1920 r. Sekcję Religijno-Wyznaniową wyodrębniono z Departamentu I i przeorganizowano w Samodzielną Sekcję Wyznań Obcych. Natomiast 24 marca tego roku, na mocy zarządzenia MSWojsk., raz jeszcze zmieniono nazwę wojskowej organizacji duszpasterskiej na Sekcję Wyznań Niekatolickich i Opieki nad Grobami Wojennymi. 12 sierpnia 1921 r. Sekcja przyjęła ostateczną nazwę Wydziału Wyznań Niekatolickich MSWojsk. W strukturze tego Wydziału znajdował się Główny Urząd Duszpasterski Wyznania Prawosławnego z ks. Bazylim Martyszem na czele ${ }^{3}$.

Priorytetowymi zadaniami Głównego Urzędu Duszpasterstwa Wyznania Prawosławnego było nadzorowanie pracy duszpasterskiej kapelanów, opieka religijna nad żołnierzami wyznania prawosławnego, opieka nad cmentarzami i grobami wojskowymi, zaopatrzenie duchowieństwa i świątyń w niezbędne utensylia cerkiewne i literaturę religijną, koordynowanie katechizacji wśród żołnierzy, prowadzenie ksiąg metrykalnych i opracowanie danych statystycznych dotyczących swoich wiernych. Szczególną rolę odgrywał Urząd w rozwiązywaniu problemów organizacji nabożeństw podczas świąt religijnych. Kwestia organizacji nabożeństw sprawiała wiele trudności z uwagi na funkcjonowanie w Kościele prawosławnym kalendarza juliańskiego 4 .

Kolejna reorganizacja w strukturze duszpasterstwa wyznań niekatolickich nastąpiła w roku 1927. Na miejsce Wydziału powołano Biuro Wyznań Niekatolickich. Struktura Biura była następująca: szef Biura, zastępca, wydział ogólny i wydziały poszczególnych wyznań. Szefami wydziałów wyznaniowych byli jednocześnie naczelni kapelani danego wyznania. Kapelani ci pełnili

\footnotetext{
${ }^{3}$ Witold Wróblewski, „Duszpasterstwo mniejszości religijnych w Wojsku Polskim w latach 1918-1939”, w: Białoruś, Czechosłowacja, Litwa, Polska, Ukraina. Mniejszości w świetle spisów statystycznych XIX-XX w., red. Jan Skarbek (Lublin, 1996), 104-105; Zofia Waszkiewicz, Duszpasterstwo w siłach zbrojnych Drugiej Rzeczypospolitej (1918-1939) (Toruń, 2000), 136-139. Por. również prace: Janusz Odziemkowski, Stużba duszpasterska Wojska Polskiego 1914-1945 (Warszawa, 1998) i Janusz Odziemkowski, Sławomir Frątczak, Polskie duszpasterstwo wojskowe (Warszawa, 1996).

${ }^{4}$ Andrzej Czesław Żak, „Prawosławny Ordynariat Wojska Polskiego II Rzeczypospolitej w świetle wojskowych źródeł archiwalnych", w: 20-lecie restytucji Prawosławnego Ordynariatu Wojska Polskiego, red. Jerzy Pańkowski (Warszawa, 2015), 17.
} 
również funkcję doradców szefa Biura Wyznań Niekatolickich MSWojsk. w sprawach wyznaniowych ${ }^{5}$.

Dwa lata później, 3 sierpnia 1929 roku, doszło do nowej reorganizacji duszpasterstwa wyznań niekatolickich. Od tego czasu kierownikowi Biura Wyznań Niekatolickich podlegało pięć Głównych Urzędów Duszpasterskich reprezentujących swoje wyznania. Jednym z nich był Główny Urząd Duszpasterski Prawosławny ${ }^{6}$. Kandydata na naczelnego kapelana prawosławnego (protoprezbitera) proponował ministrowi spraw wojskowych metropolita. Naczelnemu kapelanowi podlegali wszyscy kapelani i personel pomocniczy. Protoprezbiter wyznania prawosławnego miał obowiązek zwoływania dwa razy do roku konferencji dziekanów, którzy stanowili jego organ doradczy. Naczelnym kapelanem prawosławnym do 1935 r. był ks. Bazyli Martysz, a po nim ks. Szymon Fedorońko ${ }^{7}$.

W 1938 r. władze polskie, przychylając się do wieloletnich próśb synodu kościoła prawosławnego, wyraziły zgodę na powołanie prawosławnego biskupa polowego. 18 listopada Prezydent RP podpisał dekret o stosunku Państwa do Polskiego Autokefalicznego Kościoła Prawosławnego, w którym artykuły 65-73 dotyczyły duszpasterstwa wojskowego wyznania prawosławnego. Biskup polowy, wybrany przez hierarchię prawosławną i mianowany przez ministra, miał kierować prawosławnym duszpasterstwem wojskowym w Wojsku Polskim. Projekt powołania biskupa polowego do wybuchu II wojny światowej nie został jednak zrealizowany ${ }^{8}$.

Ostatnie zmiany organizacyjne w strukturze Biura Wyznań Niekatolickich nastąpiły 15 lutego 1935 roku. W ich wyniku struktura BWN prezentowała się następująco: szef Biura, jego zastępca i sekretariat. Szefowi podlegały Główne Wojskowe Urzędy Duszpasterstwa poszczególnych wyznań, w tym Główny

${ }^{5}$ Grzybowski, W stużbie Rzeczypospolitej, 55.

${ }^{6}$ Tamże, 56.

${ }^{7}$ Wróblewski, „Duszpasterstwo mniejszości religijnych”, 106. Obaj naczelni kapelani prawosławni tragicznie zginęli w czasie II wojny światowej. Ks. Bazyli Martysz został w 1944 r. zamordowany we własnym domu w Teratynie koło Krasnegostawu, a ks. Szymon Fedorońko zginął w Katyniu. Waszkiewicz, Duszpasterstwo w siłach zbrojnych, 140, 185; Andrzej Krzysztof Kunert, „Protoprezbiter ks. ppłk Fedorońko i biskup wojskowy gen. bryg. Sawa - symbole wierności Rzeczypospolitej”, w: 20-lecie restytucji Prawosławnego Ordynariatu Wojska Polskiego, 52-53; Kapelani Wojska Polskiego pomordowani na Wschodzie1940-1941. Materiaty i źródła do biografii duszpasterzy Wojska Polskiego z lat 1919-1939 wszystkich wyznań religijnych - ofiar zbrodni katyńskiej, red. Barbara Tarkowska (Warszawa-Mińsk Mazowiecki, 2013), 137-146; Marcin Marynowski, „Ksiądz pułkownik Szymon Fedorońko. Przyczynek do biografii naczelnego kapelana prawosławnego Wojska Polskiego". w: Wielka Wojna wyzwań duchowych. Kapelani wojskowi na froncie wschodnim 1914-1920 (Kraków, 2020), 326.

8 Żak, „Prawosłąwny ordynariat Wojska Polskiego”, 17. 
Urząd Duszpasterski Prawosławny. Zmiany w strukturze organizacyjnej nie wpłynęły na kompetencje i zadania naczelnego kapelana prawosławnego. Natomiast taka struktura przetrwała do wybuchu II wojny światowej ${ }^{9}$.

W latach dwudziestych prawosławne duszpasterstwo wojskowe liczyło około 20 duchownych. Nie wszyscy kapelani prawosławni pozostawali na etatach wojskowych - liczba kapelanów wahała się od trzynastu w 1923 r do dwudziestu trzech w 1938 roku $^{10}$. Dobór kandydatów do służby duszpasterskiej w Wojsku Polskim prowadzono skrupulatnie, etaty przyznając jedynie tym duchownym, którzy dysponowali dobrą znajomością języka polskiego, a swą postawą moralną w niczym nie uchybiali lojalności wobec państwa. Obok indywidualnej przydatności duchownych do pracy wśród żołnierzy zwracano uwagę na ich gotowość do prowadzenia polityki polonizacyjnej w środowisku prawosławnym. Każdy kandydat na kapelana był opiniowany przez MWRiOP oraz administrację państwową w terenie. W latach trzydziestych, gdy mianowano kapelanów wojskowych nie odwołując się do opinii władz cerkiewnych, dochodziło do naruszeń prawa kanonicznego ${ }^{11}$. Naczelny kapelan prawosławny - protoprezbiter otrzymał stopień pułkownika, dziekani stopień podpułkownika, starszy kapelan - majora, a kapelan - kapitana ${ }^{12}$.

Żołnierze wyznania prawosławnego stanowili w Wojsku Polskim drugą po katolikach rzymskich grupę wyznaniową. Największa ich liczba odbywała służbę przy Grodzieńskim i Brzeskim Dowództwie Okręgu Korpusu. W tych Okręgach w 1923 r. Białorusini wyznania prawosławnego stanowili odpowiednio $19 \%$ i $32 \%$, w 1927 r. $18 \%$ i $28 \%$, a w 1936 r. $17,8 \%$ i $31 \%{ }^{13}$. Według danych statystycznych z 1927 r., wśród wyznań niekatolickich żołnierze wyznania prawosławnego stanowili $59 \%$ ogólnego liczebnego stanu wojska ${ }^{14}$. Na podstawie danych narodowościowych można wnioskować, że najwięcej procentowo rekrutów wyznania prawosławnego odbywało służbę wojskową w piechocie, jeździe, służbach inżynieryjnych, łączności i w taborach, najmniej zaś w lotnictwie, wojskach technicznych i żandarmerii ${ }^{15}$.

Znacząca liczba żołnierzy wyznania prawosławnego nie była jednak przyczyną preferencyjnego traktowania działalności duszpasterskiej kapelanów.

\footnotetext{
${ }^{9}$ Grzybowski, W stużbie Rzeczypospolitej, 57.

${ }^{10}$ Tamże, 186.

${ }^{11}$ Mirosława Papierzyńska-Turek, Między tradycja a rzeczywistościa, Państwo wobec prawostawia 1918-1939 (Warszawa, 1989), 258; Waszkiewicz, Duszpasterstwo w silach zbrojnych, 142.

${ }^{12}$ Wróblewski, „Duszpasterstwo mniejszości religijnych”, 107.

${ }^{13}$ Waszkiewicz, Duszpasterstwo $w$ sitach zbrojnych, 183.

${ }^{14}$ Wróblewski, „Duszpasterstwo mniejszości religijnych”, 111.

${ }^{15}$ Waszkiewicz, Duszpasterstwo w siłach zbrojnych, 82.
} 
Zgodnie z regulaminem służby wewnętrznej z 1936 r. prawosławni rekruci składali przysięgę jako trzeci po katolikach i ewangelikach. Chociaż liczba tych ostatnich była znacznie mniejsza od wyznawców Prawosławia. Władze wojskowe, jak również państwowe, niekiedy wykorzystywały prawosławnych kapelanów do celów ingerowania w wewnętrzne sprawy Kościoła ${ }^{16}$. Zdarzały się przypadki stosowania przymusu wobec duchownych prawosławnych ${ }^{17}$.

Na uwagę zasługuje działalność biskupa grodzieńskiego Sawy, który związany był szczególnie z Dowództwem Okręgu Korpusu w Grodnie. Uczestniczył w uroczystościach wojskowych, odprawiał nabożeństwa w cerkwiach garnizonowych, współpracował z oficerami WP ${ }^{18}$. Główny Wojskowy Urząd Duszpasterstwa zlecił biskupowi Sawie dokonanie przekładu tekstów liturgicznych na język polski. Powołana pod przewodnictwem władyki grodzieńskiego komisja składała się z pracowników Studium Teologii Prawosławnej Uniwersytetu Warszawskiego i kapelanów wojskowych (ks. Szymon Fedorońko i ks. Wiktor Romanowski) ${ }^{19}$. Główny Wojskowy Urząd Duszpasterstwa finansował też działalność Prawosławnego Instytutu Naukowo-Wydawniczego w Grodnie (powołanego 6 października 1938 r.), którego współorganizatorem był biskup Sawa, oraz wspierał materialnie polskojęzyczną „Gazetę Prawosławną"20.

Sprawując swoją posługę w Wojsku Polskim, kapelani prawosławni posiadali te same uprawnienia i obowiązki, co kapelani pozostałych wyznań. Obowiązkiem każdego kapelana było niesienie posługi wśród żołnierzy swojego wyznania poprzez odprawianie nabożeństw, wygłaszanie kazań, urządzanie spotkań - pogadanek. Ponadto prawosławne duszpasterstwo wojskowe uczestniczyło w różnych uroczystościach państwowych. Uroczyste Liturgie odprawiano z okazji świąt garnizonowych, 11 listopada, w dzień urodzin Marszałka i Prezydenta. Wydane przez Urzędy Duszpasterstwa Wyznania Prawosławnego modlitewniki rozprowadzano wśród żołnierzy, wkrótce po złożeniu przez nich przysięgi ${ }^{21}$.

\footnotetext{
${ }^{16}$ Wróblewski, „Duszpasterstwo mniejszości religijnych”, 110-111.

${ }^{17}$ Waszkiewicz, Duszpasterstwo $w$ siłach zbrojnych, 186.

${ }^{18}$ Arcybiskup general brygady Sawa (Jerzy Sowietow). Wybór dokumentów, opr. Krzysztof Filipow i Andrzej Schucitz (Białystok-Warszawa, 1997), 9; Tadeusz Kryska-Karski, Stanisław Żurakowski, Generalowie Polski Niepodległej, wyd. 2 uzupełnione i poprawione (Warszawa, 1991), 160; Anna Radziukiewicz, „Sawa (Sowietow) Wojskowy Biskup Prawosławny w Armii Andersa” w: Nieść pokój, kochać ludzi, Arcybiskup generat dywizji Miron (Chodakowski) 1957-2010, red. Anna Radziukiewicz (Warszawa, 2011), 38-43; Kunert, „Protoprezbiter ks. ppłk. Fedorońsko”, 52-53.

${ }^{19}$ Arcybiskup generat brygady Sawa (Jerzy Sowietow). Wybór dokumentów, 189.

${ }^{20}$ Papierzyńska-Turek, Między tradycją a rzeczywistościa, 233, 237.

${ }^{21}$ Grzybowski, W stuzbie Rzeczypospolitej, 90.
} 
Trudno było organizować parafie w garnizonach, gdzie znajdowały się niewielkie grupki żołnierzy prawosławnych. W takich wypadkach kapelan raz w miesiącu odwiedzał dany garnizon, żeby odprawić nabożeństwo i przeprowadzić rekolekcje ${ }^{22}$.

Niektóre decyzje i działania władz wojskowych, w okresie międzywojennym, wobec żołnierzy i wiernych wyznania prawosławnego były nie do końca zrozumiałe i kładły się cieniem na wzajemne relacje. W niektórych okręgach wojskowych władze pozostawiały żołnierzy prawosławnych bez posługi kapelańskiej $^{23}$. Likwidacji uległy duszpasterstwa prawosławne przy Dowództwie Okręgu Korpusu w Łodzi (1922) i Przemyślu (1928). Ograniczono w ten sposób zakres funkcjonowania duszpasterstwa do wielkich miast: Wilna, Grodna, Torunia, Krakowa, Lwowa, Lublina i Brześcia ${ }^{24}$. Nie przynosiło chluby polskiemu wojsku zaangażowanie się Korpusu Ochrony Pogranicza w akcję rewindykacyjno-polonizacyjną we wschodnich województwach II Rzeczypospolitej. Korpus Ochrony Pogranicza był również odpowiedzialny za współudział w niszczeniu cerkwi prawosławnych na Chełmszczyźnie i Podlasiu w 1938 r.

\section{II WOJNA ŚWIATOWA}

W czasie II wojny światowej kontynuowano prace Prawosławnego Ordynariatu Polowego. Jego zwierzchnik, biskup Sawa, dał się poznać jako gorący polski patriota. Przebywając w Stanach Zjednoczonych, w swojej działalności publicznej wielokrotnie poruszał kwestie polskie. Wielkim echem odbił się jego list pasterski z 23 lutego 1943 r. do duchowieństwa i wiernych, zwracający baczną uwagę na tysiącletnią tradycję prawosławia w Polsce ${ }^{25}$.

Podczas pobytu w Stanach Zjednoczonych w latach 1940-1943 biskup Sawa zapraszany był na spotkania z przedstawicielami innych kościołów. Uczestniczył w nabożeństwach oraz w zjazdach organizowanych w Nowym Jorku jak i na prowincji. Utrzymywał bliskie kontakty z przedstawicielami Patriarchatu Ekumenicznego. Dużą życzliwością obdarzał biskupa Sawę grecki metropolita w Nowym Jorku Athenagoras ${ }^{26}$.

22 Janusz Odziemkowski, Armia i społeczeństwo II Rzeczypospolitej (Warszawa, 1996), 72.

${ }^{23}$ Krystyna Gomółka, „Białorusini w II Rzeczypospolitej”, Zeszyty Naukowe Politechniki Gdańskiej. Ekonomia 31(1992), 144.

${ }^{24}$ Waszkiewicz, Duszpasterstwo w siłach zbrojnych, 184-185.

${ }^{25}$ Kunert, „Protoprezbiter, ks. ppłk Fedorońko”, 61-62.

${ }^{26}$ Arcybiskup general brygady Sawa (Jerzy Sowietow). Wybór dokumentów, 10. 
Biskupa wybrano również na honorowego prezesa bardzo poważnej instytucji amerykańskiej Anglo-Orthodox Fellowship. Poza posługą na rzecz polskich obywateli przebywających w USA, spotykał się z profesorami i teologami anglikańskimi, wspomagał akcje polskie związane z Polskimi Siłami Zbrojnymi na Zachodzie. Nawiązał też i utrzymywał dobre kontakty z duchowieństwem prawosławnym na Wschodzie, co miało wielkie znaczenie w kontekście zmieniającej się sytuacji politycznej. W Europie Rosja Sowiecka stała się członkiem koalicji antyhitlerowskiej. Na terenie Rosji powstała armia polska dowodzona przez gen. Władysława Andersa. Stało się więc niezmiernie ważną rzeczą objęcie posługą duszpasterską żołnierzy polskich wyznania prawosławnego ${ }^{27}$.

Wtedy to zrodziła się idea utworzenia duszpasterstwa wojskowego wyznania prawosławnego. Trzeba było tylko odtworzyć przedwojenne struktury. W kręgach rządowych przypomniano sobie wówczas o biskupie Sawie, który był osobą znaną i uznawaną nie tylko w środowisku polskich polityków, ale także na terenie Anglii i na kontynencie europejskim. Ważnym atutem była znajomość z wieloma patriarchami i biskupami kościołów wschodnich. Po uzgodnieniach rządowych i za aprobatą Prezydenta Rzeczypospolitej Polskiej postanowiono powierzyć biskupowi Sawie stanowisko wojskowego biskupa prawosławnego ${ }^{28}$.

Powołanie bpa Sawy na prawosławnego ordynariusza wojskowego wywołało spór w łonie władz państwowych. Komitet polityczny Rady Ministrów na swym nadzwyczajnym posiedzeniu w dniu 23 października 1943 r. zgłosił w tej sprawie wiele uwag, koncentrując się na kwestiach prawnych uniemożliwiających jego natychmiastową nominację. Dekret Prezydenta RP z 1938 r. i statut wewnętrzny Kościoła prawosławnego z 1939 r. przewidywały powołanie biskupa wojskowego $\mathrm{w}$ porozumieniu $\mathrm{z}$ urzędującym metropolitą warszawskim. W tym czasie metropolita Dionizy przebywał w kraju pod okupacją niemiecką i wszelki z nim kontakt w tej sprawie był uniemożliwiony. Komitet Polityczny zaproponował powołanie bpa Sawy na głównego kapelana, jednak nie w randze generała, a na stanowisku pułkownika. Minister Spraw Wewnętrznych Władysław Banaczyk w piśmie z 27 października 1943 r. adresowanym do premiera rządu wskazywał, że taka postawa Komitetu Politycznego jest wyrazem nietolerancji religijnej. Po licznych negocjacjach ostatecznie przyjęto rozwiązanie kompromisowe, mianując biskupa Sawę pełniącym obowiązki wojskowego biskupa prawosławnego w randze generała brygady czasu wojny ${ }^{29}$.

\footnotetext{
${ }^{27}$ Tamże, 12.

${ }^{28}$ Kunert, „Protoprezbiter, ks. ppłk Fedorońko”, 63.

${ }^{29}$ Arcybiskup generat brygady Sawa (Jerzy Sowietow). Wybór dokumentów, aneksy 9-14; Zbigniew Werra, Działalność duszpasterska w 2 Korpusie Polskich Sit Zbrojnych na Zachodzie gen.
} 
Do dyspozycji biskupa 5 stycznia 1944 r. oddano cerkiew w Edynburgu, adaptowaną ze świątyni protestanckiej. W Świętej Liturgii uczestniczyło około trzystu wojskowych ${ }^{30}$. Podczas Świąt Wielkanocnych 1944 r. zorganizowano dla wiernych transport samochodowy do Edynburga. W pierwszej Liturgii na Święto Zmartwychwstania Pańskiego uczestniczyli przedstawiciele najwyższych władz wojskowych i państwowych ${ }^{31}$.

Pod koniec II wojny światowej w 1945 r. duszpasterstwo prawosławne zostało rozbudowane dzięki powołaniu do służby nowych kapelanów wojskowych. Awanse uzyskali liczni przedstawiciele duchowieństwa prawosławnego. Był wśród nich ks. Konstanty Siemaszko, który uzyskał nominację na pułkownika. W lutym 1945 r. odwiedził on I Dywizję Pancerną generała Maczka, odbywał też duszpasterskie podróże wizytacyjne po Włoszech oraz Bliskim i Środkowym Wschodzie. Kapelanem prawosławnym Dywizji Pancernej został ks. Jan Krasowski, który przybył z II Korpusu. Na jego miejsce duszpasterzem prawosławnym II Korpusu został ks. Wsiewołod Jaśkow. W pracy duszpasterskiej pomagał mu dotychczasowy kapelan II Korpusu, ks. Jan Sotniew ${ }^{32}$. W składzie II Korpusu służyło w tym czasie 2342 żołnierzy prawosławnych ${ }^{33}$.

Po zakończeniu wojny bp Sawa, korzystając z pomocy rządu angielskiego, zwizytował ponad trzydzieści polskich obozów okupacyjnych w Niemczech. Podczas jednej z takich wizyt mianował kapelana Wojska Polskiego ks. Tichona Kirylczuka swoim delegatem i dziekanem na teren okupowany przez wojska amerykańskie, a kapelana ks. Apollona Nowickiego uczynił delegatem i dziekanem na teren okupowany przez wojska brytyjskie ${ }^{34}$.

Pod koniec roku 1942 na terenie Wielkiej Brytanii przebywało ponad trzystu żołnierzy prawosławnych. Liczba żołnierzy uległa wkrótce zwiększeniu z powodu przysłania kolejnych uzupełnień ze Środkowego Wschodu. Brak duszpasterstwa prawosławnego wywoływał rozgoryczenie ze strony współwyznawców. Ministerstwo Spraw Zagranicznych zareagowało zdecydowanie zwracając uwagę na niepożądane aspekty polityczne wynikające z zaistniałej sytuacji. Po licznych konsultacjach podjęto decyzję o poszukaniu odpowiedniego kandydata. Okazał się nim ks. Michał Bożerianow, duszpasterz prawosławny I Korpusu przebywającego na Wschodzie, który opuścił Polskę we

Władystawa Andersa 1941-1947 (Warszawa, 2009), 214-215; Grzybowski, W stużbie Rzeczypospolitej, 290-303.

${ }^{30}$ Odziemkowski, Stużba, 208-209.

${ }^{31}$ Grzybowski, W stużbie Rzeczypospolitej, 305.

32 Tamże, 357-358.

${ }^{33}$ Kunert, „Protoprezbiter ks ppłk Fedorońko”, 65; Werra, Działalność duszpasterska, 215.

${ }^{34}$ Arcybiskup generat brygady Sawa (Jerzy Sowietow). Wybór dokumentów, aneksy 15-16. 
wrześniu 1939 r. Sprowadzenie kapelana do Wielkiej Brytanii napotkało jednak na liczne przeszkody ${ }^{35}$.

W tej sytuacji na stanowisko tymczasowego kapelana powołano 20 lipca 1943 r. ks. Aleksego von der Mensbrugghe, obywatela Wielkiej Brytanii. Decyzja Ministerstwa Obrony Narodowej została podjęta po uprzednim porozumieniu z metropolitą Germanosem, przedstawicielem Patriarchatu Konstantynopolitańskiego na Europę. Ks. Aleksy von der Mensbrugghe miał sprawować opiekę nad żołnierzami prawosławnymi do czasu objęcia tej funkcji przez kapelana pochodzącego z Autokefalicznego Kościoła Prawosławnego w Polsce ${ }^{36}$.

Kapelani prawosławni w czasie II wojny światowej podzielili los wszystkich żołnierzy polskich. Żołnierze prawosławni walczyli na wszystkich frontach II wojny światowej, na których złożyli daninę krwi. Po zakończeniu wojny żołnierzom wyznania prawosławnego zakazano odbywania praktyk religijnych w Siłach Zbrojnych Polskiej Rzeczypospolitej Ludowej, a do sprawy ordynariatu polowego powrócono dopiero po 1989 r. $^{37}$.

\section{BIBLIOGRAFIA}

Arcybiskup generat brygady Sawa (Jerzy Sowietow). Wybór dokumentów. Opr. Krzysztof Filipow, Andrzej Sucheitz. Białystok-Warszawa: Ośrodek Badań Historii Wojskowej Muzeum Wojska, 1997.

Biskup Miron. „Z dziejów prawosławnego ordynariatu wojskowego w Rzeczypospolitej”. W: Chrześcijaństwo, Kościól, Prawosławie. Białystok, 2003.

Gomółka Krystyna, „Białorusini w II Rzeczypospolitej”. Zeszyty Naukowe Politechniki Gdańskiej. Ekonomia 31(1992).

Grzybowski, Jerzy. W stużbie Rzeczypospolitej. Duszpasterstwo wojskowe wyznania prawosławnego w Wojsku Polskim w latach 1919-1949. Warszawa, 2016.

Kapelani Wojska Polskiego pomordowani na Wschodzie1940-1941. Materiaty i źródta do biografii duszpasterzy Wojska Polskiego z lat 1919-1939 wszystkich wyznań religijnych - ofiar zbrodni katyńskiej. Red. Barbara Tarkowska. Warszawa-Mińsk Mazowiecki, 2013.

Kryska-Karski, Tadeusz i Stanisław Żurakowski. Generałowie Polski Niepodległej, wyd. 2 uzupełnione i poprawione. Warszawa, 1991.

Kunert, Andrzej Krzysztof. „Protoprezbiter ks. ppłk Fedorońko i biskup wojskowy gen. bryg. Sawa - symbole wierności Rzeczypospolitej”. W: 20-lecie restytucji Prawosławnego Ordynariatu Wojska Polskiego. Red. Jerzy Pańkowski. Warszawa, 2015.

\footnotetext{
${ }^{35}$ Antoni Mironowicz, „Polskie prawosławne duszpasterstwo cywilne w Afryce”, Wiadomości PAKP (2001), 5(138): 12-17.

${ }^{36}$ Tamże, 17.

${ }^{37}$ Bp Miron, „Z dziejów prawosławnego ordynariatu wojskowego w Rzeczypospolitej”, w: Chrześcijaństwo. Kościót. Prawosławie (Białystok, 2003), 23-41.
} 
Marynowski, Marcin. „Ksiądz pułkownik Szymon Fedorońko. Przyczynek do biografii naczelnego kapelana prawosławnego Wojska Polskiego". W: Wielka Wojna wyzwań duchowych. Kapelani wojskowi na froncie wschodnim 1914-1920. Kraków, 2020.

Mironowicz Antoni. „Polskie prawosławne duszpasterstwo cywilne w Afryce”. Wiadomości PAKP (2001), 5(138).

Odziemkowski, Janusz. Armia i spoleczeństwo II Rzeczypospolitej. Warszawa, 1996.

Odziemkowski, Janusz i Bolesław Spychała. Duszpasterstwo wojskowe w Drugiej Rzeczypospolitej. Warszawa, 1987.

Odziemkowski, Janusz. Stużba duszpasterska Wojska Polskiego w latach 1914-1945. Warszawa, 1998.

Odziemkowski, Janusz i Sławomir Frątczak. Polskie duszpasterstwo wojskowe. Warszawa, 1996.

Papierzyńska-Turek, Mirosława. Między tradycja a rzeczywistością. Państwo wobec Prawosławia 1918-1939. Warszawa, 1989.

Radziukiewicz, Anna. „Sawa (Sowietow) Wojskowy Biskup Prawosławny w Armii Andersa”. W: Nieść pokój, kochać ludzi, Arcybiskup generat dywizji Miron (Chodakowski) 1957-2010. Red. Anna Radziukiewicz. Warszawa, 2011.

Waszkiewicz, Zofia. Duszpasterstwo w silach zbrojnych Drugiej Rzeczypospolitej (1918-1939). Toruń, 2000.

Werra, Zbigniew. Działalność duszpasterska w 2 Korpusie Polskich Sił Zbrojnych na Zachodzie gen. Władystawa Andersa 1941-1947. Warszawa, 2009.

Wróblewski, Witold. „Duszpasterstwo mniejszości religijnych w Wojsku Polskim w latach 1918-1939”. W: Białoruś, Czechosłowacja, Litwa, Polska, Ukraina. Mniejszości w świetle spisów statystycznych XIX-XX wieku. Red. Jan Skarbek. Lublin, 1996.

Żak, Andrzej Czesław. „Prawosławny Ordynariat Wojska Polskiego II Rzeczypospolitej w świetle wojskowych źródeł archiwalnych". W: 20-lecie restytucji Prawosławnego Ordynariatu Wojska Polskiego. Red. Jerzy Pańkowski. Warszawa, 2015.

\section{PRAWOSŁAWNE DUSZPASTERSTWO WOJSKOWE W OKRESIE MIĘDZYWOJENNYM I W TRAKCIE II WOJNY ŚWIATOWEJ}

Streszczenie

Powyższy artykuł prezentuje w zarysie trudny okres rozwoju Prawosławia na terenie II Rzeczypospolitej, czyli lata 1918-1945. Problemy z uksztaltowaniem jednoznacznej myśli państwowej, ustalenie profilu konfesyjnego czy wreszcie tragedia II wojny światowej ukazywały już wcześniej istniejące problemy bądź ewokowały nowe. Naturalna skłonność do kultywowania tradycji chrześcijaństwa zachodniego na ziemiach polskich musiała wreszcie ustąpić powojennym uwarunkowaniom programu ateistycznego, gdy wojsko stanęło na straży wierności narzuconym treściom traktatowym, by strzec wolności w jej nowych semantycznie ograniczeniach.

Słowa kluczowe: historia; wojskowość; wojna; teologia; duszpasterstwo prawosławne. 